\title{
Electro-chemical charge characteristics of surface-subsurface region of selected soils in the tropics
}

\section{Sourav Kumar Khan *, Sanjib Kar}

Department of Agricultural Chemistry \& Soil Science, Institute of Agricultural Science, University of Calcutta, India

\begin{abstract}
A study was conducted to investigate the relation between soil chemical, mineralogical properties and surface charge characteristics of selected tropical soils in West Bengal, India. The objectives of this study were to analyse the electro-chemical charge characteristics of surface-subsurface soils in accordance with point of zero charge (PZC) and pH-dependent charge. Subsoil's generally have higher PZC than corresponding surface horizons and $\mathrm{pH}$ dependent surface charges are maximum in upper layer than that of other. Relatively lower value of $\mathrm{PZC}\left(\right.$ or $\mathrm{pH}_{0}$ ) along the depth, mostly affected by organic matter, clay content free $\mathrm{Fe}$ and $\mathrm{Al}$ oxides. Result shows that $\mathrm{PZC}\left(\mathrm{or} \mathrm{pH}_{0}\right.$ ) values decrease with increasing organic matter content and increase with increase in sesquioxides content. The PZC of the charge-pH curves in Diamond Harbour soil (DH) $(0-45 \mathrm{~cm})$ was on the acid side of the zero point titration indicate that the samples possess permanent negative charge and in Raigunj soil (RG) (30$45 \mathrm{~cm}$ ) was on basic side possess slight permanent positive charge. Amount of surface charge reduces along the depth (subsurface region) than corresponding surface region except in RG $(30-45 \mathrm{~cm})$ due to considerable increase in positive charges by presence of various electrolyte or synthetic hematite as $\alpha-\mathrm{Fe}_{2} \mathrm{O}_{3}$. PZC has the strong negative correlation with $\mathrm{pH}$-dependent charge $\left(r=-0.85707^{*}\right)$ that supports the superiority of the present study. Regression value also supports the strong dependency of electrochemical surface charge on PZC and organic matter content of corresponding soil layers $\left(R^{2}=0.971474\right)$.
\end{abstract}

\section{Article Info}

Received : 28.06.2019

Accepted : 24.10 .2019

Keywords: Electro-chemical charge, surface-subsurface, soils, tropics.

(C) 2020 Federation of Eurasian Soil Science Societies. All rights reserved

\section{Introduction}

Surface charge properties have an important bearing on the migration of ions in soil, the formation of organo-mineral complexes, soil structure, plant nutrition, and the dispersion, flocculation, swelling, and shrinkage of the soil fractions (Zhang and Zhao, 1997). The surface charge of variable charge constituents depends on the pH and ionic strength of soil solution (van Raij and Peech, 1972; Naidu et al., 1994). Variable surface charge is attributed to the ionisation of functional groups on organic matter, hydrous $\mathrm{Fe}$ and $\mathrm{Al}$ oxides, and edge sites on kaolin by protonation and deprotonation processes (Phillips and Sheehan, 2005). Surface charge can be positive, negative, or zero depending on conditions of the soil solution. Surface sites of these soil constituents generally have net positive charge under acidic conditions (Qafoku et al. 2004). Moreover, adsorbed organic anions (Xu et al., 2003), phosphate (Naidu et al., 1990), and sulfate on surfaces contribute to negative surface charge (Bolan and Barrow 1984; Fahrenhorst et al., 1999).

Parks and de Bruyn (1962) distinguished two types of electrical double layer on the basis of the mechanism by which free charges are distributed across a solid solution interface; (i) a reversible double layer which exists on surface bearing constant potential, and (ii) a completely polarisable double layer which exists on surfaces bearing constant charge. The constant potential model applies to soil minerals such as $\mathrm{Fe}$ and $\mathrm{Al}$ oxides, hydroxides while constant charge model applies to layer silicate mineral such as smectite and vermiculite which bear permanent negative surface charges due to isomorphous substitution (van Raij and

\footnotetext{
${ }^{*}$ Corresponding author. 700019 India

Department of Agricultural Chemistry \& Soil Science, Institute of Agricultural Science, University of Calcutta, 35, B.C.Road, Kolkata- 
Peech, 1972; Keng and Uehara, 1973). The most suitable phenomenon for predicting the charge dependent fingerprint of oxide minerals is the point of zero charge (PZC). The PZC of an oxide mineral is the pH at which the net surface charge from all sources is zero (Parks, 1967).

Point of zero charge often denoted as $\mathrm{pH}_{0}$ is one of the most important parameters used to describe variable charge surfaces (Barale et al., 2008). The balance of surface charge in a soil is developed from the perspective of coordination chemistry and is employed to derive the conditions under which the zero point of charge is equal either to the crossover point of two proton titration curves or to the point of zero net charge (Sposito, 1981). Uehara and Gillman (1981) indicated that $\mathrm{pH}_{0}$ is the $\mathrm{pH}$ where the amounts of negative and positive charge of variable charge components where these are equal. Point of zero charge varies with soil according to the variation of organic matter and sesquioxide/allophane content. Charge characteristics of soil are a function of organic carbon content and mineralogical composition of soil (Khan and Kar, 2018).

The previous studies showed that the $\mathrm{pH}_{0}$ values decrease with increasing organic matter content and increase with increase in sesquioxides (Hou et al., 2007; Anda et al., 2008; Sharami et al., 2010). Interaction among amorphous materials and crystalline minerals in the clay fraction may result in certain modification of the surface and subsurface charge characteristics of the soil system. The constant potential colloids such as $\mathrm{Fe}$ and $\mathrm{Al}$ oxides play a crucial role in influencing the physical and chemical properties of highly weathered soils in tropics. This paper reports the electrochemical charge characteristics of surfacesubsurface region of selected soils in the tropics.

\section{Material and Methods}

\section{Sampling sites}

Six soil samples were collected from Diamond Harbour of South 24 parganas and Raigunj of Uttar Dinajpur district of West Bengal, India. The soils are mostly tropical climate with an annual rainfall of approximately $1250 \mathrm{~mm}$ and mean temperature of approximately $24.8{ }^{\circ} \mathrm{C}$ (Metrological Department, 2018). The sampling sites and classification of the soils in this study are given in Table1. The soil samples are air dried, crushed, and then passed through $2 \mathrm{~mm}$ sieve for laboratory analysis.

Table 1. Sampling site, Soil order, Vegetation Type, Parent material, Genetic horizon, Texture and Textural class

\begin{tabular}{|c|c|c|c|c|c|c|c|}
\hline Sl.No. & Location & $\begin{array}{l}\text { Soil } \\
\text { order }\end{array}$ & $\begin{array}{l}\text { Soil } \\
\text { Classification }\end{array}$ & $\begin{array}{l}\text { Vegetation } \\
\text { type }\end{array}$ & $\begin{array}{l}\text { Parent } \\
\text { material }\end{array}$ & $\begin{array}{l}\text { Genetic } \\
\text { horizon }\end{array}$ & $\begin{array}{l}\text { Textural } \\
\text { Class }\end{array}$ \\
\hline 1. & $\begin{array}{l}\text { Diamond Harbour } \\
\text { Soil (DH), West } \\
\text { Bengal, India. } \\
22.19^{\circ} \mathrm{N}, 88.20^{\circ} \mathrm{E}\end{array}$ & Fluvaquent & $\begin{array}{l}\text { Fine-loamy, } \\
\text { Aeric Epiaquepts }\end{array}$ & $\begin{array}{l}\text { Rice-rice- } \\
\text { rice }\end{array}$ & $\begin{array}{l}\text { Deltaic } \\
\text { Alluvium }\end{array}$ & $A p-B w-B C$ & $\begin{array}{l}\text { Silty clay } \\
\text { loam }\end{array}$ \\
\hline 2. & $\begin{array}{l}\text { Raigunj Soil (RG), } \\
\text { West Bengal, India } \\
26.32^{0} \mathrm{~N}, 89.45^{0} \mathrm{E}\end{array}$ & Haplaquept & $\begin{array}{l}\text { Fine-loamy, } \\
\text { Typic } \\
\text { Dystrustepts }\end{array}$ & $\begin{array}{l}\text { Tropical } \\
\text { decudious } \\
\text { forest }\end{array}$ & $\begin{array}{l}\text { Indo- } \\
\text { Gangetic } \\
\text { Alluvium } \\
\end{array}$ & A-Bw-BC & $\begin{array}{l}\text { Clay } \\
\text { loamy }\end{array}$ \\
\hline
\end{tabular}

\section{Physico-chemical analysis}

Soil $\mathrm{pH}$ as measured in a 1:1 soil : solution in $\mathrm{H}_{2} \mathrm{O}$ and $1 \mathrm{M} \mathrm{KCl}$ (National Soil Survey Centre, 1996), Organic Carbon (OC) was measured by the Walkley-Black method (Nelson and Sommers, 1996) and used to calculate the amount on Organic matter (OM) $(\mathrm{OM}=\mathrm{OCx} 1.742)$. Cation exchange capacity was determined by $\mathrm{NH}_{4} \mathrm{OAC}$ at pH 7.0 and is defined by the some of the exchangeable cations that a soil can absorb (Chapman, 1965). Anion exchange capacity is determined by colorimetric methods (Clarke, 1950). Particle size distribution was analysed by the pipette method (Gee and Bauder, 1986). The $\Delta \mathrm{pH}$ index was calculated from the difference between $\mathrm{pH}_{\mathrm{KCl}}$ and pHwater (Mekaru and Uehara, 1972). Calcium and Magnesium estimated by Sparks (1996). Exchangeable Al and Fe were estimated by Bertsch and Bloom, 1996 and Sparks, 1996 respectively. The Fe and $\mathrm{Al}$ contents associated with secondary minerals were determined in extracts obtained after boiling both $1 \mathrm{~g}$ of soil for 30 minutes in $20 \mathrm{ml} 9(\mathrm{M}) \mathrm{H}_{2} \mathrm{SO}_{4}$. The acid extract were analysed for $\mathrm{Al}$ and $\mathrm{Fe}$. Soil fused with alkali and total Fe and Al estimated by atomic absorption spectrometry (AAS) (Sparks, 1996). Mineralogy of synthesized precipitates (Clay) was determined by X-ray powder diffraction analysis.

\section{Surface charge analysis}

\section{i.Potentiometric titrations}

The procedure described by van Raij and Peech (1972) was used. A series of 4g soil samples was equilibrated with known amounts of acid $(\mathrm{HCl})$ and base $(\mathrm{KOH})$ in various concentration of $\mathrm{KCl}(1,0.1,0.01$, $0.001 \mathrm{~N}$ ) for 3 days in a closed humidified glass container to prevent evaporation. The $\mathrm{pH}$ of supernatant solution was determined using a $\mathrm{pH}$ meter with micro glass electrode and a recorder after centrifugation. 
The amount of $\mathrm{H}^{+}$and $\mathrm{OH}^{-}$ion adsorbed at a given $\mathrm{pH}$ value is equal to the amount of $\mathrm{HCl}$ and $\mathrm{KOH}$ added after correction for the amount of acid or base required to bring the electrolyte solution alone to the corresponding $\mathrm{pH}$ value. The surface charge or adsorption density, $\left(\sum \mathrm{H}^{+}-\sum \mathrm{OH}\right)$, is then plotted against the equilibrium $\mathrm{pH}$ of the system. The PZC of the soil is taken as the $\mathrm{pH}$ value where the charge-pH curves measured in different electrolyte concentrations intersect one another (Parks and de Bruyn, 1962).

\section{ii.Determination of electric charges}

The procedure involves saturating a series of $4 \mathrm{~g}$ soil samples with $1 \mathrm{~N} \mathrm{KCl}$ solution, adjusting the pH to desired values with $\mathrm{KOH}$ and $\mathrm{HCl}$. After equilibrium is attained, the suspensions were first washed 3 times with $0.2 \mathrm{~N} \mathrm{KCl}$ solution, then 8 times with $\mathrm{KCl}$ of desired concentrations $(1,0.1,0.01,0.001 \mathrm{~N})$ by centrifugation for fine adsorption of ions. The solutions were pre-adjusted to desired $\mathrm{pH}$ values. Finally, the $\mathrm{K}^{+}$and $\mathrm{Cl}^{-}$were then extracted 5 times with $0.5 \mathrm{~N} \mathrm{NH}_{4} \mathrm{NO}_{3}$. Correction was made for the entrapped $\mathrm{K}^{+}$and $\mathrm{Cl}^{-}$ in the equilibrium solution. Potassium was determined on a flame photometer and chloride by potentiometric titration using Beckman chloride electrode.

\section{Statistical analysis}

Each experiment was treated as a completely randomized design. Because the experiments were performed individually on each soil, comparisons of surface charge of the soils as a function of $\mathrm{pH}$ were accomplished by the use of correlation coefficient, were used to determine statistical significance of any differences in the surface charge measurements.

\section{Results and Discussion}

Important soil chemical and physical properties of the soil used in this study are given in Table 2 . Where it can be seen that phase wise samples of Raigunj soils (RG) are more acidic (4.82) compare to Diamond Harbour soils (DH) (6.10). Diamond Harbour soils are poor in organic carbon $(1.26 \%)$ than Raigunj soils $(1.85 \%)$. Cation exchange capacity (CEC) of the Raigunj soil $\left(46.4 \mathrm{cmol}_{\mathrm{c}} \mathrm{kg}^{-1}\right)$ is more compare to native Diamond Harbour soil $\left(28.3 \mathrm{cmol}_{\mathrm{C}} \mathrm{kg}^{-1}\right)$ indicates the highest ion exchange property of that soil. All these experimental soils had $\Delta \mathrm{pH}$ less than zero, which indicate they present negative net surface charge (Mekaru and Uehara, 1972). In both soils, production of negative charge along the depth was decreases due to presence of lower amount of organic matter and higher amount of sesquioxide/allophane content. Li and Xu (2008) reported that the layer silicate clays (2:1 clays) decreased the PZC or $\mathrm{pH}_{0}$ values, while the 1:1 clay minerals as kaolinite increased the $\mathrm{pH}_{0}$. Besides, Uehara and Gillman (1981) reported that the oxides of Fe and $\mathrm{Al}$ have high $\mathrm{pH}_{0}$ values ( $\mathrm{pH}$ 7-9), while silica $\left(\mathrm{SiO}_{2}\right)$ and organic matter have low $\mathrm{pH}_{0}$ values. Therefore, the low levels of $\mathrm{pH}_{0}$ in the present study were probably related to layer silicate clays $(2: 1$ clays) and high $\mathrm{pH}$ in the entire surface-subsurface horizon. Clay as well as organic matter content in Raigunj soil was significantly higher than the Diamond Harbour soil and this is enhances the corresponding cation exchange capacity of soils and also indicated the dominance of layer silicate 2:1 mineral in the clay fraction of this soil.

Table 2. Chemical and physical characteristics of soils

\begin{tabular}{|c|c|c|c|c|c|c|}
\hline \multirow{2}{*}{ Soil characteristics } & \multicolumn{3}{|c|}{ Diamond Harbour Soil (DH) } & \multicolumn{3}{|c|}{ Raigunj Soil (RG) } \\
\hline & $0-15 \mathrm{~cm}$ & $15-30 \mathrm{~cm}$ & $30-45 \mathrm{~cm}$ & $0-15 \mathrm{~cm}$ & $15-30 \mathrm{~cm}$ & $30-45 \mathrm{~cm}$ \\
\hline pH in water & 6.10 & 5.92 & 5.87 & 4.82 & 4.65 & 4.62 \\
\hline $\mathrm{pH}$ in $1 \mathrm{~N} \mathrm{KCl}$ & 5.88 & 5.74 & 5.70 & 4.17 & 4.14 & 4.11 \\
\hline${ }^{*} \Delta \mathrm{pH}$ & -0.22 & -0.18 & -0.17 & -0.65 & -0.51 & -0.51 \\
\hline $\mathrm{EC}, \mathrm{mSm}^{-1}$ & 0.12 & 0.07 & 0.04 & 0.27 & 0.13 & 0.10 \\
\hline OC, \% & 1.26 & 0.97 & 0.72 & 1.85 & 1.21 & 0.98 \\
\hline $\mathrm{OM}, \%$ & 2.17 & 1.67 & 1.24 & 3.19 & 2.08 & 1.68 \\
\hline CEC, CmolcKg $^{-1}$ & 28.30 & 28.0 & 27.5 & 46.40 & 45.20 & 44.60 \\
\hline Exchangeable Fe, g.kg-1 & 0.24 & 0.18 & 0.09 & 0.67 & 0.68 & 0.72 \\
\hline Exchangeable Al g.kg-1 & 0.13 & 0.15 & 0.11 & 0.56 & 0.62 & 0.66 \\
\hline Total Fe, g.kg-1 & 26.50 & 22.20 & 15.40 & 58.20 & 61.40 & 66.70 \\
\hline Total Al, g.kg-1 & 0.34 & 0.25 & 0.13 & 0.95 & 0.96 & 1.02 \\
\hline $\mathrm{Al}_{2} \mathrm{O}_{3}$, g.kg-1 & 11.50 & 10.20 & 7.80 & 24.20 & 22.60 & 22.30 \\
\hline $\mathrm{Si}$, g.kg-1 $^{-1}$ & 0.24 & 0.28 & 0.20 & 1.05 & 1.16 & 1.24 \\
\hline $\mathrm{SiO}_{2}$, g.kg-1 & 2.36 & 1.87 & 1.04 & 17.20 & 17.60 & 16.50 \\
\hline $\mathrm{SiO}_{2}$, g.kg-1 & 5.02 & 3.98 & 2.21 & 36.60 & 37.40 & 35.10 \\
\hline Clay, \% & 28.00 & 24.00 & 18.00 & 37.00 & 28.00 & 27.00 \\
\hline Minerals & \multicolumn{3}{|c|}{ Hydrated \& Disordered Kaolinite } & Kaolinite/l & ysite,vermicu & ith chlorite \\
\hline
\end{tabular}

\section{Surface charge-pH Curves}

The surface charge-pH curves for all soil samples measured in the four $\mathrm{KCl}$ concentrations $(1,0.1,0.01$ and $0.001 \mathrm{~N}$ ) intersect one another in accord with the constant potential model for soil colloids (Figure 1). The 
point of zero charge or $\mathrm{pH}_{0}$ values ranged from $\mathrm{pH} 1.5$ to 3.4 (Table 3). With increasing the percent of organic matter and clay content point of zero charge reduces. In present study a significant relationship observed between PZC and content of soil organic matter and clay ( $\mathrm{r}=-0.97147^{*}$ and $-0.96692^{*}$ respectively). The result can be ascribed the positive correlation between clay and organic matter contents with $\mathrm{pH}$ dependent surface charge $\left(\mathrm{r}=0.950988^{* *}\right.$ and $0.871071^{* *}$ respectively). Regression value also supports the strong dependency of electrochemical surface charge on PZC and organic matter content of corresponding soil layers $\left(\mathrm{R}^{2}=0.971474\right)$.

Table 3. PZC, pH-dependent charge and their relation with various chemical characters

\begin{tabular}{|c|c|c|c|c|c|c|}
\hline & \multicolumn{3}{|c|}{ Diamond Harbour Soil (DH) } & \multicolumn{3}{|c|}{ Raigunj Soil (RG) } \\
\hline & $0-15 \mathrm{~cm}$ & $15-30 \mathrm{~cm}$ & $30-45 \mathrm{~cm}$ & $0-15 \mathrm{~cm}$ & $15-30 \mathrm{~cm}$ & $30-45 \mathrm{~cm}$ \\
\hline $\mathrm{PZC}^{*}$ & 2.60 & 3.10 & 3.40 & 1.60 & 2.50 & 2.70 \\
\hline pH-dependent charge $\left(\mathrm{cmol}_{\mathrm{c}} \mathrm{kg}^{-1}\right)$ & 2.50 & 1.80 & 1.10 & 3.20 & 2.10 & 2.50 \\
\hline \multicolumn{7}{|c|}{ Correlation Coefficients (r) values } \\
\hline Between PZC \& pH-dependent charge & \multicolumn{6}{|c|}{-0.857070} \\
\hline Between soil pH \& PZC & \multicolumn{6}{|c|}{0.576696} \\
\hline Between PZC \& Ex. Fe & \multicolumn{6}{|c|}{-0.702170} \\
\hline Between Ex. Fe \& pH-dependent charge & \multicolumn{6}{|c|}{0.666889} \\
\hline Between PZC \& Ex. Al & \multicolumn{6}{|c|}{-0.610720} \\
\hline Between Ex. Al \& pH-dependent charge & \multicolumn{6}{|c|}{0.551042} \\
\hline
\end{tabular}

Regression value (PZC \& OM) $\left(\mathrm{R}^{2}\right)$

0.971474

In all cases, the $\mathrm{PZC}$ or $\mathrm{pH}_{0}$ occurred below the natural $\mathrm{pH}$ value of the soil indicating that the soil colloids bear net negative charges under natural conditions. This is also in agreement with negative delta $\mathrm{pH}$ values, $\left(\Delta \mathrm{pH}=\mathrm{pH}_{\mathrm{KCl}}-\mathrm{pH}_{\text {water }}\right)$, of the soils (Table 2). The PZC of the charge- $\mathrm{pH}$ curves was on the acid side of the zero point titration has been attributed to the presence of permanent negative charge (van Raij and Peech, 1972). The relative low PZC values of the surface soils in both the Diamond Harbour (DH) and Raigunj soils (RG) may be attributed to the large amounts of silicate clay minerals and $\mathrm{SiO}_{2}$ present in the soil in addition to the effect of the organic matter. The $\mathrm{PZC}$ of kaolinite and $\mathrm{SiO}_{2}$ occurs at $\mathrm{pH} 3.5$ (3.4) and 2 (1.6) respectively (Parks, 1967) that supports the present investigation (Table 3). Presence of small amounts of specifically adsorbed $\mathrm{Si}$, Fe and $\mathrm{Al}$ oxides may also contribute to low PZC and higher pH-dependent surface charge of the soils used in this study.

In all cases, the PZC values were on the acid side of the zero point titration except in RG $(30-45 \mathrm{~cm})$, may due to presence of specifically adsorbed sulphate ions that increases the positive charges on the soil colloid (Figure 1f). The magnitude of both positive and negative charges as measured by $\mathrm{K}^{+}$and $\mathrm{Cl}$ - retention as a function of $\mathrm{pH}$ and electrolyte concentration is in good agreement with the charge-pH curves of both the soils (Figures 1).

The source of permanent negative charges is apparently due to structural substitutions in 1:1 type layer silicate and $\mathrm{Fe}$ oxides since the subsurface soil samples do not contain any detectable amount of smectite type layer silicates (Gallez et al., 1975). Evidence has also been reported indicating the presence of permanent positive charges in soils due to structural substitution of $\mathrm{Ti}^{4+}$ for $\mathrm{Fe}^{3+}$ in $\mathrm{Fe}$ oxide (Sumner and Davidtz, 1965). However, soils used in this study contain negligible amount of permanent positive charge as indicated by $\mathrm{Cl}^{-}$adsorption (Figure 1f).

\section{Conclusion}

This result indicates that for the topsoil's, OM contributes substantially to $\mathrm{pH}$-dependent CEC. The positive charge of the soil increased due to removal of OM, possibly due to adsorbed OM complexes being removed from the surface of $\mathrm{Fe}$ and $\mathrm{Al}$ oxides and kaolin exposing more variable positive charge sites. The charge characteristics of these two highly weathered soils indicate that clay, mineral layer silicate and Fe oxides provides permanent negative surface charges and sesquioxide/allophane gives the permanent positive charges that play an important role on net surface charge. Point of zero charge varies with soil according to the variation of organic carbon and $\mathrm{Fe}, \mathrm{Al}$ and $\mathrm{Si}$ content. The present study draws the information about the electrochemical charge characteristics of various surface subsurface soils in tropics. 


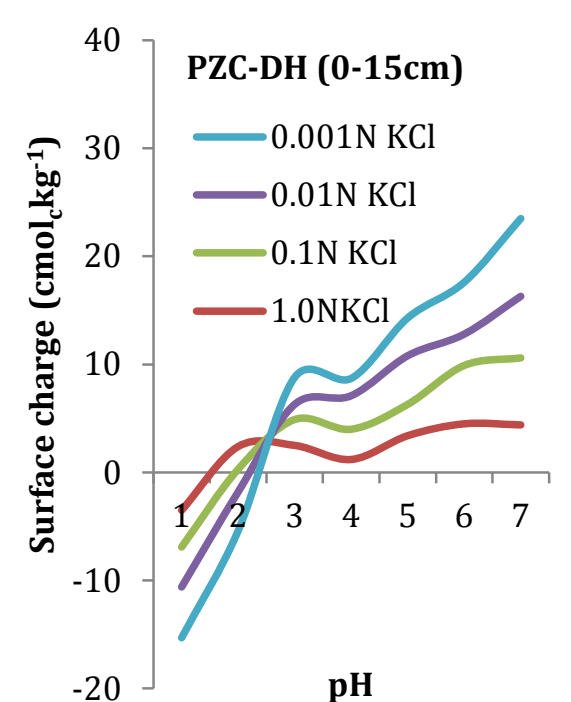

(a)

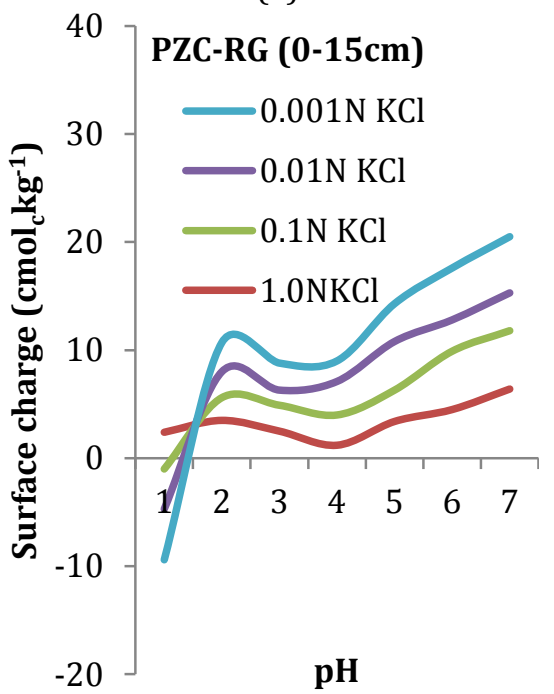

(d)

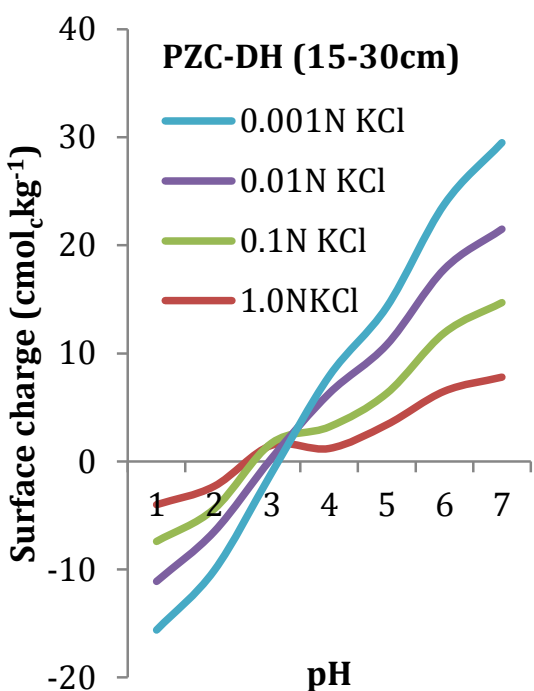

(b)

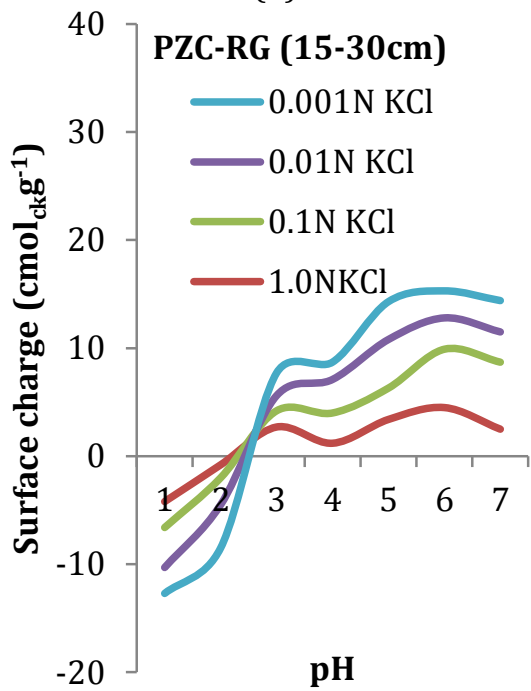

(e)

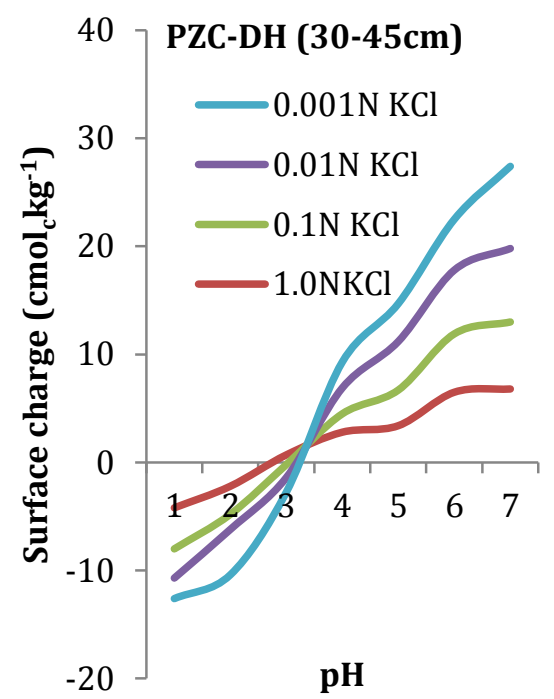

(c)

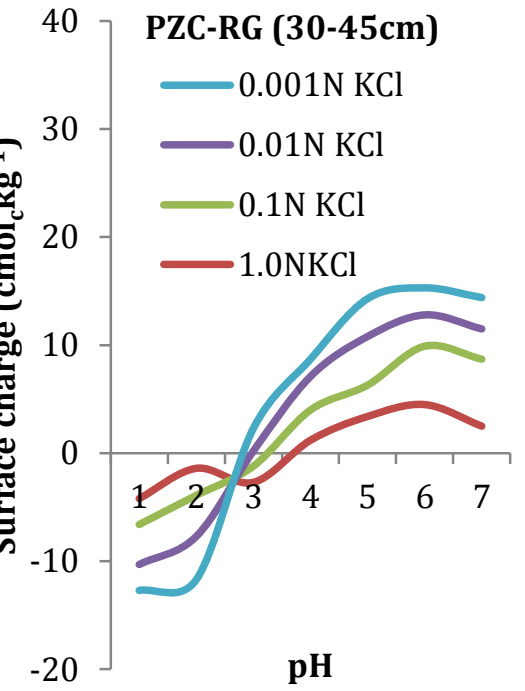

(f)

Figure 1. Surface charge-pH curves of soils determined in $\mathrm{KCl}$

\section{Acknowledgements}

The authors owed to University of Calcutta for Payodhinath Mukherjee Research Fund as a financial support for this investigation. The authors also thanks to the staff in the department of Agricultural Chemistry and Soil Science, University of Calcutta, for their kind assistance.

\section{References}

Anda, M., Shamshuddin, J. C., Fauziah, I., Omar, S.R.S., 2008. Mineralogy and factors controlling charge development of three Oxisols developed from different parent materials. Geoderma 143(1-2): 153-167.

Barale, M., Mansour, C., Carrette, F., Pavageau, E.M., Catalette, H., Lefèvre, G., Pavageau, E.M., Fedoroff, M. Cote, G., 2008. Characterization of the surface charge of oxide particles of PWR primary water circuits from 5 to $320{ }^{\circ} \mathrm{C}$. Journal of Nuclear Materials 381(3): 302-308.

Bertsch, P.M., Bloom, P.R., 1996. Aluminum. In: Methods of Soil Analysis, Part 3 - Chemical Methods. Sparks, D.L., Page, A.L., Helmke, P.A., Loeppert, R.H., Soltanpour, P.N., Tabatabai, M.A., Johnston, C.T., Sumner, M.E. (Eds.). American Society of Agronomy Inc., Madison, Wisconsin, USA. pp. 517-550.

Bolan, N.S., Barrow, N.J., 1984. Modelling the effect of adsorption of phosphate and other anions on the surface charge of variable charge oxides. European Journal of Soil Science 35(2): 273-281.

Chapman, H.D., 1965. Cation exchange capacity. In: Methods of soil analysis Part 2 Chemical and Microbiological Properties. Black, C.A. (Ed.). Agronomy No. 9. American Society of Agronomy (ASA) - Soil Science Society of America (SSSA), Madison, Wisconsin, USA. pp. 891-901.

Clarke, F.E., 1950. Determination of chloride in water - Improved colorimetric and titrimetric methods. Analytical Chemistry 22(4): 553-555.

Fahrenhorst, C., Botschek, J., Skowronek, A., Ferraz, J., 1999. Application of gypsum and lime to increase cation adsorption of a Geric Ferralsol in the Brazilian Amazon region. Journal of Plant Nutrition and Soil Science 162(1): 41-47. 
Gallez, A., Juo, A.S.R., Herbillon, A., Moormann, F.R., 1975. Clay mineralogy of selected soils in southern Nigeria. Soil Science Society of America Journal 39(3): 577-585.

Gee, G.W., Bauder, J.W., 1986. Particle-size Analysis. In: Methods of Soil Analysis, Part 2, Chemical and Microbiological Properties, A.L. Page, R.H. Miller, D.R. Keeney (Eds.), 2nd Edition. Agronomy Monograph No. 9, American Society of Agronomy, Soil Science Society of America. Madison, Wisconsin, USA. pp. 383-411.

Hou, T., Xu, R., Tiwari, D., Zhao, A., 2007. Interaction between electrical double layers of soil colloids and Fe/Al oxides in suspensions. Journal of Colloid and Interface Science 310(2): 670-674.

Keng, J.C.W., Uehara, G., 1973. Chemistry, mineralogy and taxonomy of Oxisols and Ultisols. Soil and Crop Science Society of Florida Proceedings 33: 119-126.

Khan, S.K., Kar, S., 2018. Surface charge is a function of organic carbon content and mineralogical compositions of soil. Eurasian Journal of Soil Science 7(1): 59-63.

Li, S.Z., Xu, R.K., 2008. Electrical double layers' interaction between oppositely charged particles as related to surface charge density and ionic strength. Colloids and Surfaces A 326(3): 157-161.

Mekaru, T., Uehara, G., 1972. Anion adsorption in Ferruginous tropical soils. Soil Science Society of America Journal 36(2): 296-300.

Metrological Department, 2018. Government of India, Regional Metrological Centre, Kolkata

Naidu, R., Syers, J.K., Tillman, R.W., Kirkman, J.H., 1990. Effect of liming and added phosphate on charge characteristics of acid soils. European Journal of Soil Science 41(1): 157-164.

Naidu, R., Bolans, N.S., Kookana, R.S., Tiller, K.G., 1994. Ionic-strength and pH effects on the sorption of cadmium and the surface charge of soils. European Journal of Soil Science 45(4): 419-429.

National Soil Survey Center, 1996. Soil Survey Laboratory Methods Manual. U.S. Department of Agriculture, National Soil Survey Center, Soil Survey Laboratory. Soil Survey Investigation No. 42. Version J.

Nelson, D.W., Sommers, L.E., 1982. Total carbon, organic carbon, and organic matter. In: Methods of Soil Analysis, Part 2. Chemical and Microbiological Properties. Page, A.L, Miller, R.H., Keeney, D.R. (Eds.). 2nd Edition. Agronomy Monograph, vol. 9. ASA and SSSA, Madison, WI, USA. pp. 539-579.

Parks, G.A., 1967. Aqueous surface chemistry of oxides and complex oxide minerals.Isoelectric point and zero point of charge: in Eqilibrium concepts in Natural water system. Advances in Chemistry 67: 121-160.

Parks, G.A., de Bruyn, P.L., 1962. The zero point of charge of oxides. Journal of Physical Chemistry 66(6): 967-973.

Phillips, I.R., Sheehan, K.J., 2005. Importance of surface charge characteristics when selecting soils for wastewater reuse. Australian Journal of Soil Research 43(8): 915-927.

Qafoku, N.P., van Ranst, E., Noble, A., Baert, G., 2004. Variable charge soils: their mineralogy, chemistry and management. Advances in Agronomy 84: 159-215.

Sharami, S.M., Forghani, A., Akbarzadeh, A., Ramezanpour, H., 2010. Mineralogical characteristics and related surface charge fluctuations of some selected soils of temperate regions of northern Iran, Clay Minerals 45(3): 327-348.

Sparks, D.L., 1996. Methods of soil analysis Part 3 Chemical methods. Soil Science Society of America. Book Series No. 5. ASA, SSSA, Madison, WI, USA.

Sposito, G., 1981. The operational definition of the zero point of charge in soils. Soil Science Society of America Journal 45(2): 292-297.

Sumner, M.E., Davidtz, J.C., 1965. Positive and negative charges in some Natal Soils. South African Journal of Agricultural Science 8(4): 1045-1050.

Uehara, G., Gillman, G.P., 1981. The Mineralogy, chemistry and physics of tropical soils with variable charge clays. Boulder, Colorado. Westview Press, Boulder, Colo, USA,

van Raij, B., Peech, M., 1972. Electrochemical properties of some oxisols and alfisols of the tropics. Soil Science Society of America Journal 36(4): 587-593.

Xu, R., Zhao, A., Ji, G., 2003. Effect of low-molecular-weight organic anions on surface charge of variable charge soils. Journal of Colloid and Interface Science 264(2): 322-326.

Zhang, X.N., Zhao, A.Z., 1997. Surface charge. In: Chemistry of variable charge soils. Yu, T.R. (Ed.). Oxford University Press, New York, USA. pp. 17-63. 